\title{
A Cross Sectional Study Highlighting the Sensitivity Patterns and Incidence of Extended Spectrum Beta Lactamase Producing Klebsiella oxytoca in Patients with Urinary Tract Infection
}

\author{
Saba Abdul Razzaque1, Qamar Aziz², Syed Furqan Hassan ${ }^{3}$, Muhammad Saboor ${ }^{4}$, \\ SharmeenNaz ${ }^{5}$, Neeta Maheshwary ${ }^{6 *}$, ZarghoonaWajid ${ }^{7}$ and Adnan Anwar ${ }^{8}$ \\ ${ }^{1}$ B.S, M. Phil, Department of pathology, Baqai medical university. \\ ${ }^{2}$ MBBS, M. Phil, Professor, Department of pathology, Islam Medical college, Sialkot \\ ${ }^{3}$ MBBS, M. Phil Head of pathology National Institute of Child Health \\ ${ }^{4}$ AssisantProfessor Department of Medical Laboratory and Technology College of Applied Medical Sciences Jazan \\ University KSA \\ ${ }^{5}$ Medical officer Dow University of Health MBBS Sciences \\ ${ }^{6}$ Manager Medical Affairs and Clinical Research Hilton Pharma Pvt ltd. \\ ${ }^{7}$ MBBS M. Assistant Musavvir Stem cell clinic and pathology laboratory \\ ${ }^{8}$ MBBS.Senior Lecturer Department of Physiology Altibri Medical College Karachi
}

Received: 01 March, 2017; Accepted: 13 April, 2017; Published: 24 April, 2017

*Corresponding author: Dr. Neeta Maheshwary Sr. Director Medical, Regulatory \& business development, Hilton Pharma Pvt ltd, Pakistan; E-mail : neeta_maheshwary@yahoo.com

\begin{abstract}
Background and objective: Urinary tract infections (utis) due to multi-drug resistant Klebsiella oxytoca are increasing worldwide and have become a major public health problem.The aim of this study was to determine the current and local antimicrobial susceptibility pattern and frequency of ESBL positive strain of urinary K.oxytoca isolates.

Material and methods: This is cross sectional observational and multicenter study with the use of non-probability sampling technique. Duration of the study was February 2015 to 2016. Sample size was calculated by the prevalence of $20 \%$ with the level of significance 0.05 . The ethical approval was taken from Baqai medical university Karachi. In this study 600 presumptively Klebsiella oxytoca were collected in urine samples. For confirmation of isolates they were sub cultured on MacConkey and Cystine lactose electrolyte deficient (CLED) agar plates. On the subsequent day colony morphology were observed and gram staining was performed. For biochemical identification Rap ID ONE of Remel company kits were used.

A total 600 isolates of K.oxytoca from urine sample were taken from different microbiology laboratory of Karachi. Isolates were further confirmed by morphological and biochemical identification (rapid ONE). Confirmed K.oxytoca isolates were subjected to antibiotic sensitivity testing by Kirby Bauer disc diffusion method and ESBL identification by CLSI guidelines by using the Cephalosporins (cefotaxime), Amoxycillin-clavulanic acid and Aztreonam discs.

Results: During the study period after morphological biochemical identification and sample size calculation, only urinary 247 were confirmed as K.oxytoca. Out of which 166 (67\%) containing adult female were isolated. Children (male and female) and adult male isolated samples were approximately equal with $41(17 \%)$ and $40(16 \%)$.The most effective antibiotic were imipenem (94.7\%), amikacin (92.3\%), nitrofurantoin (84.6\%), piperacillintazobactam (83.4\%), gentamicin (65.5\%) and amoxycillin-clvulanic acid (51.4\%). These drugs show good result in both ESBL and non- ESBL strain of K.oxytoca. Results showed that 74 (29.95\%) were ESBL positive with higher frequency in adult males 21(52.5\%).
\end{abstract}

Conclusions: K.oxytoca was resistant to Third generation Cephalosporins. Our results showed higher incidence of ESBL-positive isolates. The antibiotic showing greater effectiveness toward K.oxytoca in both ESBL and non-ESBL isolates were imipenem and amikacin

Keywords: Klebsiella oxytoca; UTI; Amikacin; Imipenem; Nitrofurantoin; ESBL; 


\section{Introduction}

Urinary tract infection (UTI) is the most prevalent infectious disease worldwide after respiratory and gastrointestinal infection. [1,2]It may involve urethra, bladder or kidney [3] Urine itself has several antibacterial features that suppress UTIs. Any interference in the normal flow of urine will be the risk of UTI. [4]Different causative agent are involves for causing UTI but 95\% cases bacteria are the major cause[5]It remains a major public health problem in terms of health; about 150 million cases occurs per annum worldwide [6] Incidence of UTI in female was $60 \%$ and in male 40\% in Pakistan.[7]

Among pathogenic bacteria that cause UTIs, K.oxytoca is the second most common among Gram-negative Klebsiella specie.[2]K.oxytoca were more resistant to commonly used antibiotic compared to K. pneumoniae.[8]They were naturally least susceptible to cefoperazone and fosfomycin[9] $\beta$ - lactam antimicrobial agents are most common treatment option for such infection.[10]In clinical laboratories, these species identify only to genus level. Several studies reported different incidence rates of K.oxytoca in UTI with greater variation. The incidence was documented to be 13\% in Sudan, 20\% in Nepal whereas in Peshawar and Karachi, it was found to be $6.6 \%$ and $49 \%$ respectively. [11-14]

The development of drug resistant pathogens in patients with UTIs is increasing day by day. It is the matter of debate globally, that varies according to geographical and regional location .[15]Many factors play in the emergence of resistance from poor utilization of antimicrobial agents to transmission of resistant bacteria, instead of using narrow spectrum antibiotics use of broad-spectrum antibiotic is another reason of bacterial resistance.[16]

ESBL-producing bacteria like K.oxytoca secrete $\beta$ - Lactamase enzyme that disturbs the four-ring structure of penicillin and cephalosporin groups of antibiotic.[17]ESBLs are enzymes that mediate resistant to cephalosporin and mombactams but do not affect carbapenens. ESBLs classified into four classes and K.oxytoca belongs to class $A$, it includes various plasmid mediated $\beta$-lactamases are known as extended spectrum $\beta$-lactamases. Plasmid mediate beta- lactamase are inhibited by clavulanic acid while Chromosomal mediated are inhibited by clavulanic acid, [18].

Most of the clinical isolates of Klebsiella oxytoca have been associated with low production of $\beta$-lactamase. There are no guidelines for the early phenotypic detection of ESBL in microbial laboratories. Therefore many technologist and doctors are unaware of its importance and do not know the importance and method of detection. There for the frequency of ESBL producing strain data was limited in Pakistan .Furthermore, the pattern of antimicrobial agent usage and bacterial resistance in our community should be known and considered when prescribing antimicrobial agents. The aim of this study was to find out the antibiotic sensitivity pattern and prevalence of ESBL producing K.oxytoca causing UTI.

\section{Material and Methods}

This is a cross sectional, observational and multicenter study with the use of non-probability sampling technique. Duration of the study was February 2015 to February 2016. Sample size was calculated by the prevalence of $20 \%$ with the level of significance 0.05 . A total of 247 isolates from already diagnosed case of urinary tract infection from different laboratories of Karachi were included in the study .Ethical approval was taken from Baqai medical university Karachi

This study categorized into two groups on the basis of age (children 1-12 years and adult 13 to onward) and gender For qualitative assessment single isolated colony of K.oxytoca were proceeded according to standard morphological and biochemical identification by Ra pI DONE kit of Remel Company. It is a panel of enzyme technology technique for identification of 70 species. The test bacteria were inoculated in prepared Rap ID inoculation fluid. Then suspension matched to $0.5 \mathrm{McF}$ arland index and inoculated into cavity. Panels were incubated for 4 hours at $37^{\circ} \mathrm{C}$, spot Indole reagent was added in INC and Rap ID ONE reagent was added in Proline- $\beta$-naphthylamide, $\gamma$-Glutamyl- $\beta$-naphthylamideand Pyrrolidonyl- $\beta$-naphthylamide. Subsequently the cavity was examined for reactivity by development of colour.

Antibiotic susceptibility test was perform edusing KirbyBauer disk diffusion method in accordance with Clinical and Laboratory Standards Institute (CLSI, 20014).The CLSI proposed double-disk-diffusion methods for screening of K.oxytoca ESBL production that is performed through disks of third-generation cephalo sporins (cefotaxime), amoxycillin-clavulanic acid and aztreonam. In vitro susceptibility testing for facultative anaerobic bacteria determined by the conventional agar disk diffusion method described by Kirby- Bauer therefore called as KirbyBauer disk diffusion method. Antibiotic susceptibility disc were displaced on the surface of inoculated MHA plates by using sterile forceps. After placement, the discs were pressed gently to the agar surface

Data analyzed by using SPSS Version 20.0. The percentage and frequencies of categorical data was analyzed.Chi- square was used to assess the significance. The p-value of less than 0.05 was taken as significance.

\section{Result}

Out of the 247 isolates, the incidence of $\mathrm{K}$.Oxytoca in adult females, adult males, female children, and male children was 166 (67.2\%), 40 (16.2\%), 33 (13.3\%) and 8 (3.2\%) respectively. (Fig 1)

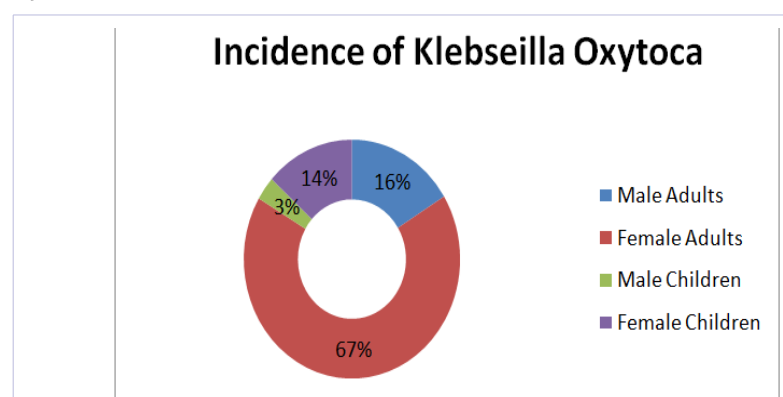

Figure 1: The incidence of Klebsiella Oxytoca 
In adult female patients two drugs imipenem and amikacin were found to be most effective 156(94\%), while in adult male patients imipenem was found to be 40 (100\%) effective and amikacin with $34(85 \%)$ effective. Whereas in children female patients fosfomycinand nitrofurantoin were found to be most effective $40(100 \%)$, while in children male patients imipenem, ami- kacin and fosfomycin were found to be most effective 32(96.9\%). Similarly the most resistant antibiotic in all the adult males, adult females, children female and children males was found to be ampicillin (Table:1).

$\mathrm{S}=$ sensitive, $\mathrm{R}=$ resistance $\mathrm{I}$ = intermediate

Table 1: Antibiogram of K.oxytoca in patients of UTI

\begin{tabular}{|c|c|c|c|c|c|c|c|c|c|c|c|c|}
\hline \multirow{2}{*}{ Antibiotics } & \multicolumn{3}{|c|}{ Adult Male $(n=40)$} & \multicolumn{3}{|c|}{ Adult Female(n=166) } & \multicolumn{3}{|c|}{ Children female $(n=8)$} & \multicolumn{3}{|c|}{ Children Male(n=33) } \\
\hline & $\begin{array}{c}\text { S } \\
\text { n (\%) }\end{array}$ & $\begin{array}{c}\mathbf{R} \\
\mathbf{n}(\%)\end{array}$ & $\begin{array}{c}\text { I } \\
\text { n (\%) }\end{array}$ & $\begin{array}{c}\text { S } \\
\text { n (\%) }\end{array}$ & $\begin{array}{c}\mathbf{R} \\
\mathbf{n}(\%)\end{array}$ & $\begin{array}{c}\text { I } \\
\text { n (\%) }\end{array}$ & $\begin{array}{c}\text { S } \\
\text { n (\%) }\end{array}$ & $\begin{array}{c}\text { R } \\
\text { n (\%) }\end{array}$ & $\begin{array}{c}\text { I } \\
\text { n (\%) }\end{array}$ & $\begin{array}{c}\text { S } \\
\text { n (\%) }\end{array}$ & $\begin{array}{c}\mathbf{R} \\
\mathbf{n}(\%)\end{array}$ & $\begin{array}{c}\text { I } \\
\text { n (\%) }\end{array}$ \\
\hline Ampicillin & $\begin{array}{c}0 \\
(0 \%)\end{array}$ & $\begin{array}{c}40 \\
(100 \%)\end{array}$ & $\begin{array}{c}0 \\
(0 \%)\end{array}$ & $\begin{array}{c}7 \\
(4.2 \%)\end{array}$ & $\begin{array}{c}158 \\
(95.1 \%)\end{array}$ & $\begin{array}{c}1 \\
(0.6 \%)\end{array}$ & $\begin{array}{c}1 \\
(12.5 \%)\end{array}$ & $\begin{array}{c}7 \\
(87.5 \%)\end{array}$ & $\begin{array}{c}0 \\
(0 \%)\end{array}$ & $\begin{array}{c}2 \\
(6 \%)\end{array}$ & $\begin{array}{c}31 \\
(93.9 \%)\end{array}$ & $\begin{array}{c}0 \\
(0 \%)\end{array}$ \\
\hline Cefixime & $\begin{array}{c}13 \\
(32.5 \%)\end{array}$ & $\begin{array}{c}26 \\
(65 \%)\end{array}$ & $\begin{array}{c}1 \\
(2.5 \%)\end{array}$ & $\begin{array}{c}53 \\
(31.9 \%)\end{array}$ & $\begin{array}{c}105 \\
(63.2 \%)\end{array}$ & $\begin{array}{c}8 \\
(4.8 \%) \\
\end{array}$ & $\begin{array}{c}1 \\
(12.5 \%)\end{array}$ & $\begin{array}{c}7 \\
(87.5 \%)\end{array}$ & $\begin{array}{c}0 \\
(0 \%)\end{array}$ & $\begin{array}{c}11 \\
(33.3 \%)\end{array}$ & $\begin{array}{c}20 \\
(60.6 \%)\end{array}$ & $\begin{array}{c}0 \\
(0 \%)\end{array}$ \\
\hline $\begin{array}{l}\text { Sulphamethoxazole- } \\
\text { trimethoprime }\end{array}$ & $\begin{array}{c}18 \\
(45 \%)\end{array}$ & $\begin{array}{c}21 \\
(52.5 \%)\end{array}$ & $\begin{array}{c}1 \\
(2.5 \%)\end{array}$ & $\begin{array}{c}65 \\
(39.1 \%)\end{array}$ & $\begin{array}{c}99 \\
(60 \%)\end{array}$ & $\begin{array}{c}2 \\
(1.2 \%)\end{array}$ & $\begin{array}{c}0 \\
(0 \%)\end{array}$ & $\begin{array}{c}8 \\
(100 \%)\end{array}$ & $\begin{array}{c}0 \\
(0 \%)\end{array}$ & $\begin{array}{c}11 \\
(33.3 \%)\end{array}$ & $\begin{array}{c}22 \\
(66.6 \%)\end{array}$ & $\begin{array}{c}0 \\
(0 \%)\end{array}$ \\
\hline Ciprofloxacin & $\begin{array}{c}16 \\
(40 \%)\end{array}$ & $\begin{array}{c}24 \\
(60 \%)\end{array}$ & $\begin{array}{c}0 \\
(0 \%)\end{array}$ & $\begin{array}{c}64 \\
(38.5 \%)\end{array}$ & $\begin{array}{c}97 \\
(58.4 \%)\end{array}$ & $\begin{array}{c}4 \\
(2.4 \%) \\
\end{array}$ & $\begin{array}{c}4 \\
(50 \%)\end{array}$ & $\begin{array}{c}4 \\
(50 \%)\end{array}$ & $\begin{array}{c}0 \\
(0 \%)\end{array}$ & $\begin{array}{c}17 \\
(51.5 \%)\end{array}$ & $\begin{array}{c}16 \\
(48.4 \%)\end{array}$ & $\begin{array}{c}0 \\
(0 \%)\end{array}$ \\
\hline Cefotaxime & $\begin{array}{c}17 \\
(42.5 \%)\end{array}$ & $\begin{array}{c}22 \\
(55 \%)\end{array}$ & $\begin{array}{c}1 \\
(2.5 \%)\end{array}$ & $\begin{array}{c}90 \\
(54.2 \%)\end{array}$ & $\begin{array}{c}70 \\
(42.1 \%)\end{array}$ & $\begin{array}{c}6 \\
(3.6 \%)\end{array}$ & $\begin{array}{c}1 \\
(12.5 \%)\end{array}$ & $\begin{array}{c}7 \\
(87.5 \%)\end{array}$ & $\begin{array}{c}0 \\
(0 \%)\end{array}$ & $\begin{array}{c}13 \\
(39.3 \%)\end{array}$ & $\begin{array}{c}16 \\
(48.4 \%)\end{array}$ & $\begin{array}{c}4 \\
(12.1 \%)\end{array}$ \\
\hline $\begin{array}{l}\text { Amoxycillin- } \\
\text { Clavulanic acid }\end{array}$ & $\begin{array}{c}15 \\
(37.5 \%)\end{array}$ & $\begin{array}{c}19 \\
(47.5 \%)\end{array}$ & $\begin{array}{c}6 \\
(15 \%)\end{array}$ & $\begin{array}{c}93 \\
(56 \%)\end{array}$ & $\begin{array}{c}63 \\
(37.9 \%)\end{array}$ & $\begin{array}{c}10 \\
(6 \%)\end{array}$ & $\begin{array}{c}4 \\
(50 \%)\end{array}$ & $\begin{array}{c}4 \\
(50 \%)\end{array}$ & $\begin{array}{c}0 \\
(0 \%)\end{array}$ & $\begin{array}{c}15 \\
(45.5 \%)\end{array}$ & $\begin{array}{c}12 \\
(36.3 \%)\end{array}$ & $\begin{array}{c}6 \\
(18.1 \%)\end{array}$ \\
\hline Gentamicin & $\begin{array}{c}17 \\
(42.5 \%)\end{array}$ & $\begin{array}{c}22 \\
(55 \%)\end{array}$ & $\begin{array}{c}1 \\
(2.5 \%)\end{array}$ & $\begin{array}{c}90 \\
(54.2 \%)\end{array}$ & $\begin{array}{c}70 \\
(42.1 \%)\end{array}$ & $\begin{array}{c}6 \\
(3.6 \%)\end{array}$ & $\begin{array}{c}3 \\
(37 \%)\end{array}$ & $\begin{array}{c}4 \\
(50 \%)\end{array}$ & $\begin{array}{c}1 \\
(12.5 \%)\end{array}$ & $\begin{array}{c}11 \\
(33.3 \%)\end{array}$ & $\begin{array}{c}19 \\
(57.5 \%)\end{array}$ & $\begin{array}{c}3 \\
(9 \%)\end{array}$ \\
\hline $\begin{array}{l}\text { Cefoperazone- } \\
\text { sulbactam }\end{array}$ & $\begin{array}{c}25 \\
(62.5 \%)\end{array}$ & $\begin{array}{c}14 \\
(35 \%)\end{array}$ & $\begin{array}{c}1 \\
(2.5 \%)\end{array}$ & $\begin{array}{c}114 \\
(68.6 \%)\end{array}$ & $\begin{array}{c}41 \\
(24.6 \%)\end{array}$ & $\begin{array}{c}7 \\
(4.2 \%) \\
\end{array}$ & $\begin{array}{c}4 \\
(50 \%) \\
\end{array}$ & $\begin{array}{c}4 \\
(50 \%) \\
\end{array}$ & $\begin{array}{c}0 \\
(0 \%)\end{array}$ & $\begin{array}{c}27 \\
(81.8 \%)\end{array}$ & $\begin{array}{c}6 \\
(18.1 \%)\end{array}$ & $\begin{array}{c}0 \\
(0 \%)\end{array}$ \\
\hline Fosfomycin & $\begin{array}{c}32 \\
(80 \%)\end{array}$ & $\begin{array}{c}7 \\
(17.5 \%)\end{array}$ & $\begin{array}{c}1 \\
(2.5 \%)\end{array}$ & $\begin{array}{c}111 \\
(66.8 \%)\end{array}$ & $\begin{array}{c}48 \\
(28.9 \%)\end{array}$ & $\begin{array}{c}7 \\
(4.2 \%) \\
\end{array}$ & $\begin{array}{c}8 \\
(100 \%)\end{array}$ & $\begin{array}{c}0 \\
(0 \%)\end{array}$ & $\begin{array}{c}0 \\
(0 \%)\end{array}$ & $\begin{array}{c}32 \\
(96.9 \%)\end{array}$ & $\begin{array}{c}1 \\
(3 \%)\end{array}$ & $\begin{array}{c}0 \\
(0 \%)\end{array}$ \\
\hline $\begin{array}{l}\text { Piperacillin- } \\
\text { Tazobactam }\end{array}$ & $\begin{array}{c}37 \\
(92.5 \%)\end{array}$ & $\begin{array}{c}2 \\
(5 \%)\end{array}$ & $\begin{array}{c}1 \\
(2.5 \%)\end{array}$ & $\begin{array}{c}138 \\
(83.1 \%)\end{array}$ & $\begin{array}{c}24 \\
(14.4 \%)\end{array}$ & $\begin{array}{c}4 \\
(2.4 \%)\end{array}$ & $\begin{array}{c}3 \\
(37 \%)\end{array}$ & $\begin{array}{c}5 \\
(50 \%)\end{array}$ & $\begin{array}{c}0 \\
(0 \%)\end{array}$ & $\begin{array}{c}28 \\
(84.8 \%)\end{array}$ & $\begin{array}{c}5 \\
(15.1 \%)\end{array}$ & $\begin{array}{c}0 \\
(0 \%)\end{array}$ \\
\hline Nitrofurantoin & $\begin{array}{c}33 \\
(82.5 \%)\end{array}$ & $\begin{array}{c}4 \\
(10 \%)\end{array}$ & $\begin{array}{c}3 \\
(7.5 \%)\end{array}$ & $\begin{array}{c}137 \\
(82.5 \%)\end{array}$ & $\begin{array}{c}18 \\
(10.8 \%)\end{array}$ & $\begin{array}{c}11 \\
(6.6 \%)\end{array}$ & $\begin{array}{c}8 \\
(100 \%)\end{array}$ & $\begin{array}{c}0 \\
(0 \%)\end{array}$ & $\begin{array}{c}0 \\
(0 \%)\end{array}$ & $\begin{array}{c}31 \\
(93.9 \%)\end{array}$ & $\begin{array}{c}1 \\
(3 \%)\end{array}$ & $\begin{array}{c}1 \\
(3 \%)\end{array}$ \\
\hline Imipenem & $\begin{array}{c}40 \\
(100 \%)\end{array}$ & $\begin{array}{c}0 \\
(0 \%)\end{array}$ & $\begin{array}{c}0 \\
(0 \%)\end{array}$ & $\begin{array}{c}156 \\
(94 \%)\end{array}$ & $\begin{array}{c}10 \\
(6 \%)\end{array}$ & $\begin{array}{c}0 \\
(0 \%)\end{array}$ & $\begin{array}{c}6 \\
(75 \%)\end{array}$ & $\begin{array}{c}2 \\
(25 \%)\end{array}$ & $\begin{array}{c}0 \\
(0 \%)\end{array}$ & $\begin{array}{c}32 \\
(96.9 \%)\end{array}$ & $\begin{array}{c}1 \\
(3 \%)\end{array}$ & $\begin{array}{c}0 \\
(0 \%)\end{array}$ \\
\hline
\end{tabular}

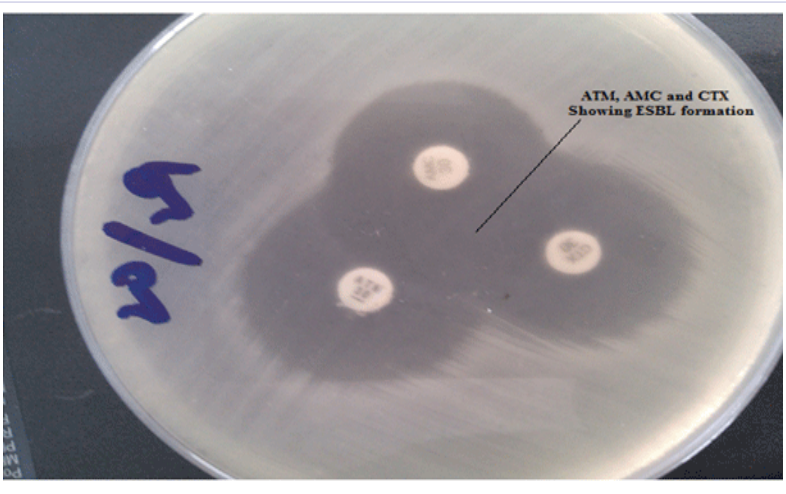

Figure 2: ESBL positive isolate of Klebsiella oxytoca

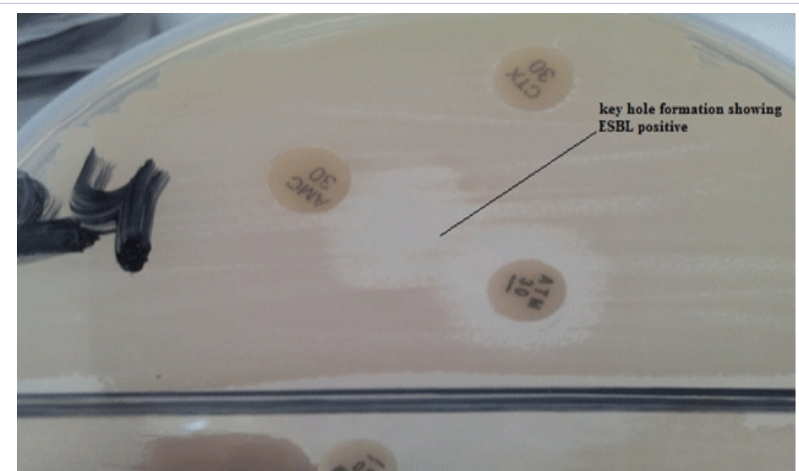

Figure 3: ESBL positive isolate of Klebsiella oxytoca

Citation: Razzaque SA, Neeta Maheshwary, et al. (2017) A Cross Sectional Study Highlighting the Sensitivity Patterns and Incidence of Extended Spectrum Beta Lactamase Producing Klebsiella oxytoca in Patients with Urinary Tract Infection. Int J Pul Inf Diseases 1(1):1-5. 
Out of 247 confirmedas K.oxytoca isolates, 74 (29.95\%) were phenotypic ESBL positive. The Chi square test on gender was statically significantly associated with ESBL outcome $\left(X^{2}=9.544\right.$, $\mathrm{P}=0.002$ ) where male adult were more likely to have positive ESBL outcome then female adult (52.5\% vs. $27.1 \%)$. Similarly, the Chi square test on gender was statically significantly associated with ESBL outcome $\left(X^{2}=11.695, P=0.03\right)$ where male children were more likely to have positive ESBL outcome then female children (62.5\%vs 9.1\%). (Table:2).

Table: 2: showing the association of adult and children isolates

\begin{tabular}{|l|l|l|l|l|}
\hline \multirow{2}{*}{ Variable } & \multicolumn{2}{c|}{ ESBL } & \multirow{2}{*}{} \\
\cline { 3 - 4 } \multicolumn{2}{|c|}{} & $\begin{array}{c}\text { Positive } \\
\text { Frequency } \\
\text { (\%) }\end{array}$ & $\begin{array}{c}\text { Negative } \\
\text { Frequency } \\
\text { (\%) }\end{array}$ & \multirow{2}{*}{ P-Value } \\
\hline \multirow{2}{*}{ Adults } & Males & $21(52.5)$ & $19(47.5)$ & 0.002 \\
\cline { 2 - 4 } & Females & $45(27.1)$ & $121(72.9)$ & \\
\hline \multirow{2}{*}{ Children } & Males & $5(62.5)$ & $3(37.5)$ & 0.03 \\
\cline { 2 - 4 } & Females & $3(9.1)$ & $30(90.9)$ & \\
\hline
\end{tabular}

Chi- Square and fisher Exact test was used to assess the significance

\section{Discusion}

Klebsiella oxytoca is the normal flora of human intestine but it causes different community acquired diseases. In clinical laboratories, K.oxytoca was misinterpreted with other Klebsiella species [19] the correct identification is important for molecular, epidemiology and bacterial grouping. This study showed the frequency, sensitivity pattern and ESBL production of K.oxytoca in UTI among children and adult patients on gender basis.

According to our isolates females have higher prevalence of UTI then men, principally owing to Anatomic and physical factors [20] when compared to Nasrulla malik et al study (2015) done in Peshawar the prevalence of Klebsiella oxytoca in females was $62.5 \%$ and in males $31.6 \%$. The incidence rate is low as compare to the Peshawar because Karachi is a well-developed metropolitan city with large population. [13]

It is establishes that Urinary tract infection is treated by antimicrobial therapy. [21] The relation between laboratory resistance and clinical outcomes are complex. [22] However, in almost all cases of UTIs, empirical antibiotic treatment initiates before the lab result of urine culture are available. Infectious disease society of America (IDSA) guidelines considers co-trimoxazole for empiric treatment of UTIs. [23]In our study, susceptibility of Cephalosporin, sulph amethoxazole -trimetho prime, ciprofloxacin and co-trimoxazole were analyzed and it was proven that these antimicrobial drugs against K.oxytoca were not effective because their sensitivity limit is below 50\%. Suylika Yvonne et al (2012) showed similar findings of co-trimoxazole below $50 \%$ sensitivity [24] The most effective drug of choice for UTI in our study were imipenem, amikacin, nitrofurantoin, piperacillin-tazobactam, gentamicin and amoxycillin-clvulanic acid which is similar to other regions of Pakistan and globally.[13,25]These drugs showed good result for the eradication of both Extended Spectrum Beta Lactamase (ESBL) and non- ESBL strain of K.oxytoca.
In one of the study in Brazil, ESBL positive K.oxytoca isolates showed the incidence of $6.9 \%$. [26]This is contradictory to our study in which we found that74 (29.95\%) were ESBL positive with higher frequency in adult males

Among ESBL producer resistance to Cefixime and Cefotaxime were $61 \%$ and $49 \%$ respectively. Therefore, it is recommended that ESBL detection should be performed daily to avoid third generation cephalo sporins. According to protocol of Center of disease control and prevention, (CDC) in vitro different level of activity against various Cephalosporins occur.[27] If cefotaxime, aztreonam and Penicillin were sensitive and strain was ESBL positive then write as resistant in reporting (CDC - FAQs about ESBLs - HAI 2010). This finding is very alarming showing highest prevalence and requires special consideration. Several factors affect the frequency of ESBL producers, which include under dose, misuse and overuse of the $\beta$-lactam drugs.[15]

Our study found that four female ESBL positive isolates were also resistant to imipenem, which is the most common alternative drugs for the treatment of ESBL producer. Imipenem acts by inhibiting cell wall synthesis and it is resistant to $\beta$-lactamase enzyme. However, use of alternative drug which is very broad spectrum and expensive drug as first line for treatment of ESBL positive bacteria will significantly increase cost of treatment and will contribute to carbapenem resistance in other bacteria. [28] The availability and indiscriminate use of commonly recommended drugs has led to an increase in resistance especially to orally administered antibiotics. Updated knowledge of the common antibiotic-sensitivity pattern must be undertaken before initiating empirical antibiotic therapy. Guidelines for the early phenotypic detection of ESBL in microbiological laboratories are mandatory due to emergence of multi-drug resistance. Whenever the infection is cause by resistant strains, the treatment becomes a great problem. International polices are no longer applicable for treating UTIs in Pakistan. Such regional surveillance programs are necessary to provide information, which can help to develop guidelines for UTI treatment in Pakistan. Also further research for screening and determination of minimum inhibitory concentration (MIC) and minimum bactericidal concentration (MBC) should be performed for the development of new drug for treatment of UTI. Furthermore, molecular studies are recommended to observe the antibiotic resistant pattern and ESBL gene among our population. ESBL identification test should be performed phenotypically to avoid indiscriminate use of broad spectrum antibiotics.

Limitation of our study is that we did not performed minimum inhibitory concentration (MIC) and minimum bactericidal concentration (MBC) for the development of new drug for treatment of Klebsiella oxytoca in UTIs. In our study although the isolates were resistant to multiple drug classes, there was a lack of beta-lactamase genes, which could be predictable to the existence of additional beta-lactamase genes. Furthermore, the study might not be immune from the Observer has an experimental bias. Considering the results of our study and to what extent they may be consistent with the minimal bacterial concentration will be enlightening for the treatment of resistant species of K. oxytoca. 


\section{Conclusion}

K.oxytoca was resistant to third generation Cephalosporins Our results showed higher incidence of ESBL-positive isolates. The antibiotic showing greater effectiveness toward K.oxytoca in both ESBL and non-ESBL isolates were imipenem and amikacin.

\section{Recommendation}

Lab tests should be mandatory for treatment against UTI to achieve appropriate drug and reduce resistant strains. Physician should be updated by the recent knowledge of antibiotic susceptibility pattern in order to reduce antibiotic resistance. With antibiotic susceptibility test phenotypically ESBL identification test should be performed to select the drug of choice. The indiscriminate use of Carbapenem may develop resistance to these important drugs, thus creating significant therapeutic problems for effective treatment.

\section{References}

1. Ahmed K, Raja I, Hussain I, Jan M, Nefees M, jahan Z, et al. Prevalence of Escherichia coli in Suspected Urinary Tract Infected Patients and Their Sensitivity Pattern Against Various Antibiotics in Gilgit-Baltistan. Pakistan J Zool. 2014;46 (6): 1783-1788.

2. Beyene G, Tsegaye W. Bacterial Uropathogens in Urinary Tract Infection and Antibiotic Susceptibility Pattern in Jimma University Specialized Hospital, Southwest Ethiopia. Ethiop J Health Sci. 2011;21(2): 141146.

3. Sadia Anwar G. Ghasi Khan,Sajjad Ahmed . Frequency of Uropathogens in different gender and age groups. Gomal J Med Sci. 2013;11(1):2023.

4. Nester E. Microbiology. Boston: McGraw-Hill; 2004.

5.Bonadio, M., M. Meini, P. Spitaleri andGigli,C.. Current microbiological and clinical aspects of urinary tract infections. European. Urol.2001;40(4):439 445.

6. C Manikadan, A.Amsath. Antibiotic susceptibility pattern of Klebsiella pneumoniae isolated from urine samples. IntJCurr Microbial App.sci. 2013;2(8):330-337.

7. Bashir M, Qazi J, Ahmad N, Riaz S. Diversity of Urinary Tract Pathogens and Drug Resistant Isolates of Escherichia coli in different age and gender Groups of Pakistanis. Trop J Pharm Res. 2008;7(3)1025-1031.

8. Vasantha .p leela K. Biotyping and Antibiotic Susceptibility Pattern of Klebsiella Isolates Recovered From Tertiary IJAR Care Hospital. 2015;5(6):473-476.

9 strains. JM. Stock I, wiedemann B. Natural antibiotic susceptibility of Klebsiella pneumoniae, K. oxytoca, K. planticola, K. ornithinolytica and K. terrigena M. 2001;50(5):396-406. DOI: 10.1099/0022-1317-50-5396

10. Savitajadhav, Rabindranath misra, Nageshawarigandham, Mahadevujagare, et al.Increasing Incidence of Multidrug Resistance Klebsiella Pneumoniae Infections InHospital And Community Settings. Inter. J. Microbiol. 2012;4(6):253-257.

11. Mekki A, Hassan A, M Elsayed D. Extended spectrum beta lactamases among multi drugs resistant Escherichia coli and Klebsiella species causing urinary tract infection in khartoum. JBR. 2010;2(3):18-21.

12. Upadhyay A , Parajuli P. Extended spectrum $\beta$ - lactamse producing multidrugs -resistant Klebsiella specie isolate at national medical college and teaching hospital, Nepal. Asian J Pharm clin Res. 2013;6(4):
161-164.

13. Nasrullah M, Mamoon A, Muneeb u. Prevalence and antimicrobial susceptibility of uropathogens in patients reporting to a tertiary care facility in Peshawar, Pakistan. J MicrobiolAntimicrob. 2015;7(1):6-12.

14. Abdullah F, Akber S, Anis W, Syedain F; . Identification of Klebsiella pneumoniae and Klebsiella oxytoca in urine specimens from a laboratory in Karachi. Microbiology Research International. 2015 3(3): 37 40.

15. Saboor M. Moinuddin Moinuddin and Samina Ilyas Comparison of platelet CD markers between normal individuals and untreated patients with type 2 Diabetes Mellitus. JHTD.2013; 2(1):380-382. doi10.4172/2329-8790.1000123

16. WHO of IM| Urinary tract infections in infants and children in developing countries in the context CI [Internet]. Who.int. 2016 [cited 28 July 2016]. Available from: http://www.who.int/child_adolescent_health/ documents/fch_cah_05_11/en/

17. Tsakris A, Poulou A, Markou F, Pitiriga V, Piperaki E, Kristo I et al. Dissemination of clinical isolates of Klebsiella oxytoca harboring CMY-31, VIM-1, and a new OXY-2-type variant in the community. AAC. 2011; 55(7): 3164-3168. doi-10..1128/AAC.00102-11

18. MumtazS,Ahmed M, Aftab I, Akhtar N, Hassan M, Hamid A. extended spectrum $\beta$-lactamases in enteric gram-negative bacilli: related to age and gender. J Ayub Med Coll Abbottabad 2007:19(4); 107-111.

19. Westbrook G, Hara C, Roman S, Miller M. Incidence and identification of Klebsiellaplanticola in clinical isolates with emphasis on newborns. J ClinMicrobiol. 2000; 38 (4): 1495-1497.

20. Kumar, M., V. Lakshmi, and Rajagopalan,R. Occurrence of extended spectrum -lactamases among Enterobacteriaceae spp. isolated at a tertiary care Institute. Indian J. Med. Microbiol.2006; 24(3): 208-211.

21. Jancel T. Management of uncomplicated urinary tract infections. West J Med. 2002; 176 (1): 51-55.

22. Davey P, Stelinke D, MacDonad T, Phillips G, Sullivan F. Not so simple cystitis: how should prescribers be supported to make informed decisions about the increasing prevalence of infections caused by drugresistant bacteria. Br J Gen Pract. 2000; 50 (451): 143-6.

23. Warren J, Abrutyn E, Hebel J, Johnson J, Schaeffer A, Stamm W. Guidelines for antimicrobial treatment of uncomplicated acute bacterial cystitis and acute pyelonephritis in women. Clin Infect Dis. 1999; 29 (4): 745-758. DOI: $10.1086 / 520427$

24. Akoachere J, Yvonne S, Akum N, Seraphine E. Etiologic profile and antimicrobial susceptibility of community-acquired urinary tract infection in two Cameroonian towns. BMC Rec Notes. 2012; 5 (1): 219. doi: 10.1186/1756-0500-5-219

25. Saha R, Farrance C, Verghese B, Hong S, Donofrio R. Klebsiella michiganensis sp. nov., A New Bacterium Isolated from a Tooth Brush Holder. CurrMicrobiol. 2012; 66 (1): 72-78. DOI: 10.1007/s00284-0120245-x

26. Miranda E, Oliveira G, Roque F, Santos S, Olmos R, Lotufo P. Susceptibility to antibiotics in urinary tract infections in a secondary care setting from 2005-2006 and 2010-2011, in Sao Paulo, Brazil: data from 11,943 urine cultures. Rev Inst Med Trop Sao Paulo. 2014; 56 (4): 313324.

27. CDC - FAQs AboutESBLs - HAI [Internet]. Cdc.gov. 2010 [cited 3 May 2016]. Available from: http://www.cdc.gov/HAI/settings/lab/lab_ esbl.html

28. Nordmann Poirel L. Emerging carbapenemases in Gram-negative aerobes. CMI. 2002; 8 (6): 321-331. 